\title{
A NEW SPECIES OF ISOPTERYGIUM (PYLAISIADELPHACEAE) FROM CENTRAL AMERICA
}

\author{
WiLLIAM R. BUCK \& BRUCE ALLEN
}

\begin{abstract}
Isopterygium zunilense (Pylaisiadelphaceae) is described from a montane cloud forest in Guatemala. It is distinguished by its large stature with leaves rounded to the insertions.

Key words: Isopterygium, Pylaisiadelphaceae, Hypnaceae, Central America, Guatemala, tropical montane cloud forest, new species.

William R. Buck, Institute of Systematic Botany, The New York Botanical Garden, Bronx, NY 10458-5126, U.S.A., e-mail: bbuck@nybg.org

Bruce Allen, Missouri Botanical Garden, P.O. Box 299, St. Louis, MO 63166-0299, U.S.A., e-mail: bruce.allen@mobot.org
\end{abstract}

\section{INTRODUCTION}

Guatemala is the northwesternmost Central American country and has the one of the highest vascular plant diversities of all the Central American nations, with over 8000 species reported (Steyermark 1950). It is well known to bryologists because of Bartram's (1949) early and useful Mosses of Guatemala. In more recent years, Allen's (1994, 2002, 2010) Moss Flora of Central America has superseded Bartram's work, but most of the pleurocarps remain to be published by Allen. During the course of routine identifications, a specimen sent to the senior author was determined to be a new species. It was collected as part of a study on the Asteraceae of Pico Zunil, a tropical montane cloud forest in southwestern Guatemala (Quedensley \& Bragg 2007). However, Quedensley is interested in cryptogams, especially lichens (see, e.g., Quedensley \& Véliz Pérez 2011), and he collected bryophytes as part of his field work.

Cloud forests in Guatemala are found on both the Sierra de las Minas in the east as well as on the slopes of the volcanic belt where they characterize the slopes facing the Pacific Ocean (Steyermark 1950). They were once common and abundant in montane Guatemala, but extensive forest clearing has been documented since the 1940s (Veblen 1978). Currently the cloud forest habitat in Central America is greatly reduced and disappearing rapidly, however, many Central American communities are now attempting to preserve nearby cloud forests because they are a principal source of clean, fresh water. Despite the relative wealth of knowledge available on Guatemalan mosses, it appears as if taxonomic novelties can still be found, even of relatively robust taxa.

\section{TAXONOMY}

Isopterygium zunilense W. R. Buck \& B. H. Allen, sp. nov. Fig. 1

TyPe: GUATEMALA. QuetZALTENANGO: Municipio de Zunil, road to Fuentes Georginas, $4 \mathrm{~km}$ south of Zunil, northwest slopes of Pico Zunil, $14^{\circ} 45^{\prime} 15.6^{\prime \prime} \mathrm{N}$, $91^{\circ} 28^{\prime} 58.4^{\prime \prime} \mathrm{W}, 2442 \mathrm{~m}$; on rock; 2 January 2006, $T$. $S$. Quedensley 3846 (HOLOTYPE NY; ISOTYPES BIGU (not seen), MO).

Plants relatively robust in golden, glossy mats. Stems creeping, to $3 \mathrm{~cm}$ long, irregularly branched; pseudoparaphyllia filamentous; axillary hairs with a single, short-rectangular, pale brown basal cell and 3-4 elongate, hyaline, apical cells; stems in 


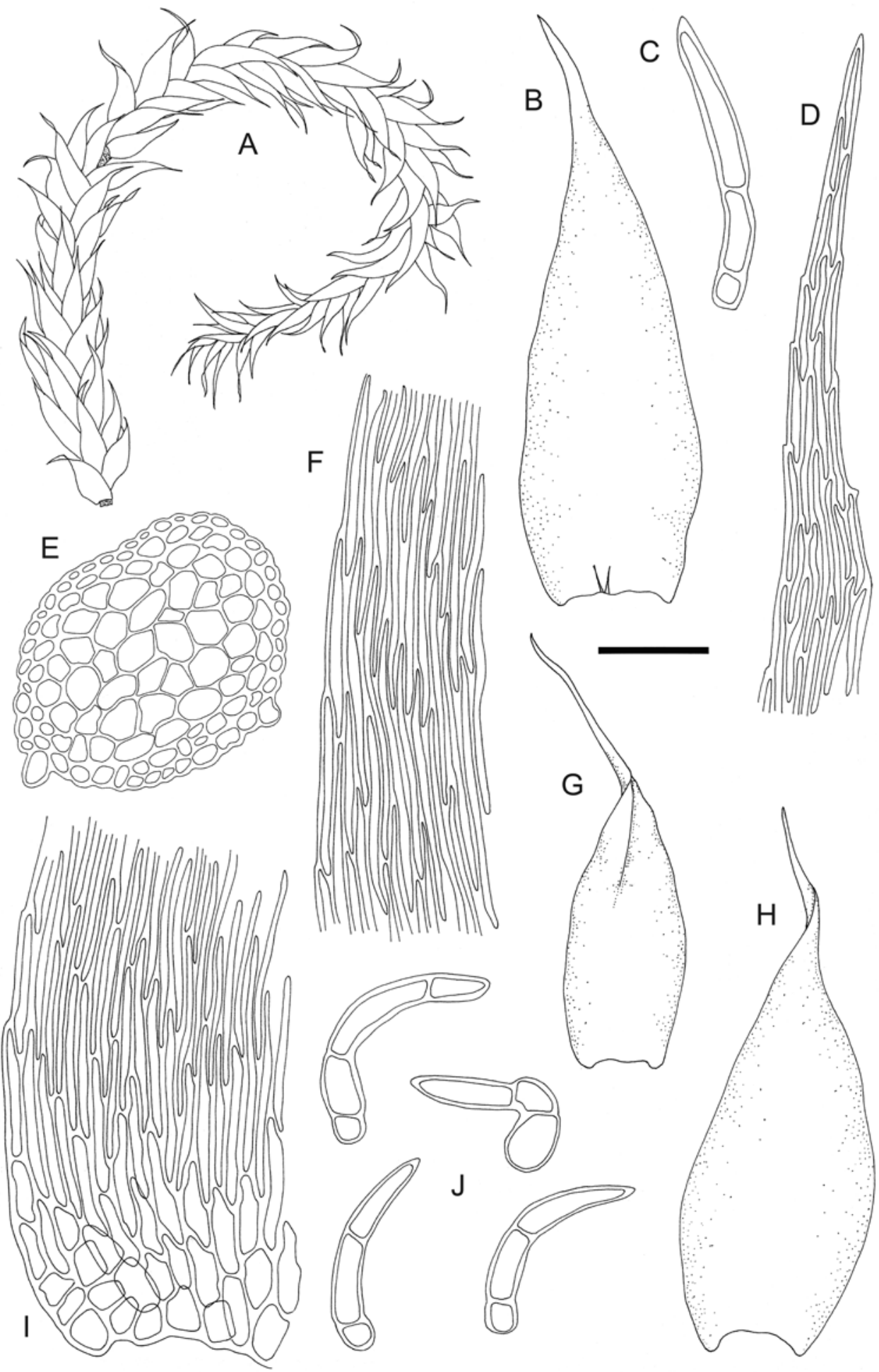


cross-section with (1-)2(-3) rows of firm-walled cells surrounding enlarged, thin-walled cortical cells, central strand absent. Leaves erect-spreading, slightly striolate when dry, \pm homomallous, oblong-ovate, $1.8-2.3 \times 0.5-0.8 \mathrm{~mm}$, gradually longacuminate, \pm rounded to the insertion, sometimes conspicuously so, not decurrent; margins plane or irregularly recurved, subentire to weakly serrulate above, entire below; costa very short and double or absent; laminal cells linear-flexuose, 85-230 $\times 3-6 \mu \mathrm{m}$, smooth, firm-walled, not porose, becoming abruptly shorter and significantly broader (to $c a 14 \mu \mathrm{m}$ ) toward the insertion in 1-2 row(s); alar cells poorly differentiated, quadrate to shortrectangular in 2-4(-6) rows, extending up the basal margins by (2-)3-4 cells. Autoicous. Perichaetial leaves lanceolate-ovate, $c a 1.2 \mathrm{~mm}$ long, ecostate. Perigonial leaves lanceolate, ca $0.7 \mathrm{~mm}$ long, ecostate. Sporophytes not known.

ETYMOLOGY. The specific epithet is derived from the name of the type locality.

DISTRIBUTION. Known only from the type collection.

HABITAT. Tropical montane cloud forest, on rocky outcrops with Fuchsia arborescens, Alnus acuminata, Stanmarkia spectabilis, Roldana gilgii, Pinus ayahuiete, Carpinus carolinianus var. tropicalis and Podachaenium eminens.

\section{DISCUSSION}

Isopterygium zunilense differs from all other Central American Isopterygium species in its large leaf size: $1.8-2.3 \mathrm{~mm}$ long vs. $0.4-1.5 \mathrm{~mm}$ long (Ireland \& Buck 2009). It is a high elevation species with an overall aspect very similar to some species of Rhynchostegiopsis or Sematophyllum swartzii (Schwägr.) W. H. Welch \& H. A. Crum. Other distinctive features of I. zunilense include: leaves clearly rounded to the insertions; at least some leaves with short, double costae; and basal cells across the insertions abruptly shorter and significantly broader than the other basal leaf cells. Isopterygium zunilense shares some features of Rhynchostegiopsis such as having leaves clearly rounded to the insertions; basal cells across the insertions abruptly shorter and significantly broader than the other basal leaf cells; and stems that lack central strands. That genus differs from I. zunilense in having naked branch primordia (i.e., no pseudoparaphyllia); sharply serrate upper leaf margins; and absolutely ecostate leaves. Sematophyllum swartzii is also similar to I. zunilense in having subentire to weakly serrulate leaf margins; very short, double, or absent costae; and stems that lack central strands. It differs from I. zunilense in having naked branch primordia (i.e., no pseudoparaphyllia); greatly enlarged and inflated alar cells; and usually yellowish or reddish basal cells across the insertions that are narrow, elongate, and often porose.

This new species might be confused with the genus Vesicularia. However, in that genus the pseudoparaphyllia are subfoliose, i.e., biseriate below, and consist of somewhat swollen, thinwalled cells that are quite different from the small, firm-walled pseudoparaphyllial cells of Isopterygium. At least in the New World, species of Vesicularia can have a central strand in their stems, as does the common Neotropical $V$. vesicularis (Schwägr.) Broth. (Buck 1998). Most often species of Vesicularia from the Neotropics also have leaves with a remarkably lax areolation, and strongly differentiated dorsal/ ventral leaves. In Isopterygium, including in I. zunilense, the dorsal and ventral leaves on a single stem are never strongly differentiated.

ACKNOWLEDGMENTS. We thank Taylor Quedensley (currently of Georgia College, Milledgeville, GA) for going beyond the Asteraceae and collecting cryptogams when he was doing his fieldwork in Guatemala, and for sending us the material for identification.

Fig. 1. Isopterygium zunilense W. R. Buck \& B. H. Allen, sp. nov. A - habit, B, G \& H - leaves, C \& J-pseudoparaphyllia, $\mathrm{D}$ - leaf apex, E - stem in cross section, $\mathrm{F}$ - median leaf cells at margin, I - basal leaf cells and alar region. Scale in mm: bar $=0.06(\mathrm{C}, \mathrm{D}, \mathrm{F}, \mathrm{I}, \mathrm{J})$; bar $=0.13(\mathrm{E})$; bar $=0.4(\mathrm{~B}, \mathrm{G}, \mathrm{H})$; bar $=1.96(\mathrm{~A})$. All from Quedensley 3846 (MO, isotype). 


\section{REFERENCES}

Allen B. 1994. Moss flora of Central America. Part 1. Sphagnaceae-Calymperaceae. Monogr. Syst. Bot. Missouri Bot. Gard. 49: 1-242.

Allen B. 2002. Moss flora of Central America. Part 2. Encalyptaceae-Symphyodontaceae. Monogr. Syst. Bot. Missouri Bot. Gard. 90: 1-699.

Allen B. 2010. Moss flora of Central America. Part 3. Anomodontaceae-Calymperaceae. Monogr. Syst. Bot. Missouri Bot. Gard. 117: 1-731.

BARTRAm E. B. 1949. Mosses of Guatemala. Fieldiana, Bot. 25: $1-442$.

BucK W. R. 1998. Pleurocarpous mosses of the West Indies. Mem. New York Bot. Gard. 82: 1-400.
IRELAND R. R. \& BUCK W. R. 2009. Some Latin American genera of Hypnaceae (Musci). Smithsonian Contr. Bot. 93: i-viii, 1-97.

Quedensley T. S. \& BragG T. B. 2007. The Asteraceae of northwestern Pico Zunil, a cloud forest in western Guatemala. Lundellia 10: 49-70.

Quedensley T. S. \& Véliz PÉREZ M. 2011. Ramalina mahoneyi, a new corticolous lichen from a western Guatemalan cloud forest. Lundellia 14: 3-7.

SteYermark J. A. 1950. Flora of Guatemala. Ecology 31: 368-372.

VEBLEN T. T. 1978. Forest preservation in the western highlands of Guatemala. Geogr. Rev. (New York) 4: 417-434.

Received 23 April 2013 